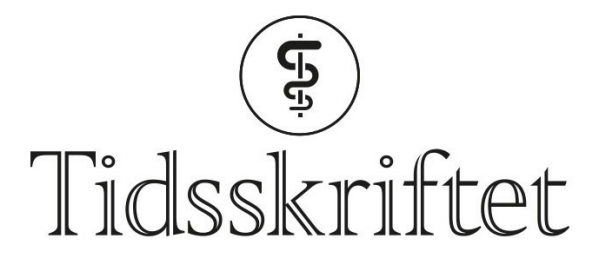

DEN NORSKE LEGEFORENING

\title{
På de 70 ooo favners dyp
}

INTERVJU

JANNIKE REYMERT

E-post: jannike.reymert@gmail.com

Verden lå bokstavelig talt for Marte Jürgensens føtter da hun fikk drømmejobben i FN, men så fikk hun ME etter en mononukleoseinfeksjon. To år seinere ble hun frisk etter sitt livs største snuoperasjon.

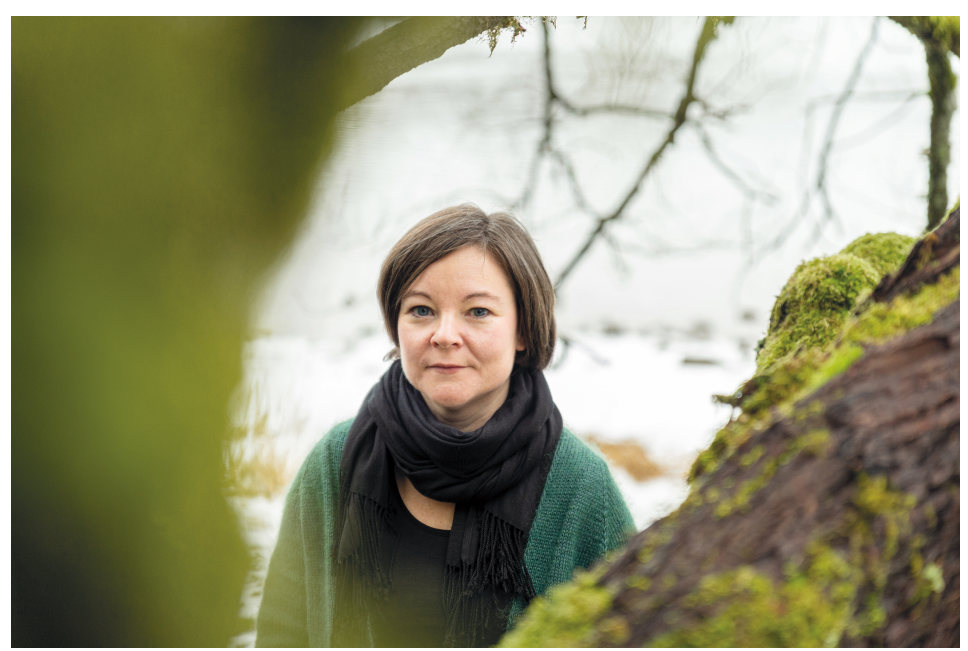

Alle foto: Magne Sandnes

Egentlig skulle hun bli fysiker.

- Det var mitt lille opprør mot den rådende holdningen om at man bør studere medisin når karakterene er gode nok. Men fysikk var litt tørt og kjedelig, og så kom tanken om at jeg ville gjøre en forskjell og bli lege. Det var vel idealisten i meg som slo inn, sier hun tørt.

Under studiet kom interessen for internasjonal helse. Det begynte med Helse uten grenser, medisinstudentenes humanitæraksjon, hvorpå hun engasjerte seg i å bygge opp Studentenes fredspris under Den internasjonale studentfestivalen i Trondheim. Så ble det to utvekslingsopphold i Sør-Afrika, og etter endt turnus begynte hun på en doktorgrad om hiv og aids i Zambia, før hun fikk drømmejobben som juniorekspert i UNAIDS. Nå skulle hun ut i verden!

\section{Sykdommen}

På vei til Uganda ble livet snudd på hodet for Marte. Hun fikk feber og halsvondt. Det gikk ikke over. I Uganda er feber av ukjent årsak alltid malaria, så hun fikk behandling med kinin før hun til slutt selv tittet seg i halsen og stilte diagnosen mononukleose. 
Marte ble veldig dårlig og innså at hun måtte reise hjem til Norge for å komme til hektene. Tilfriskningen lot vente på seg.

- Jeg gikk inn i en slags dvale. Jeg satt i en stol store deler av dagen og tenkte på at jeg burde klare å sette ting i oppvaskmaskinen før mine foreldre kom hjem fra jobb. Da jeg merket at energinivået økte litt, prøvde jeg å være litt mer aktiv, med det resultat at jeg falt sammen like utmattet som før.

\section{Marte Jürgensen}

Født 1977

Cand.med., NTNU 2005

Turnustjeneste, Haugesund og Karmøy 2005-07

Ph.d.-stipendiat, Universitetet i Bergen 2007-12

Lege i spesialisering i psykiatri, Helse Bergen 2012-16

Lege i spesialisering i psykiatri, Solli DPS 2016-19

Overlege, OCD-teamet / Klinikk for 4-dagersbehandling, Helse Bergen 2019-

- En gang jeg skulle til fastlegen, ble jeg forbigått av en gammel dame med rullator! Jeg kom inn i et mønster med mye unngåelse som jeg nå forstår var med på å opprettholde symptomene. Samtidig var det en stor tapsopplevelse å gi fra seg drømmejobben, jeg visste jeg aldri ville få en slik mulighet igjen.

- Hvordan taklet du den sorgen?

- Jeg måtte jo bare lære meg å akseptere at livet var satt på vent. På en måte ble jeg reddet av at jeg hadde så lite overskudd at jeg ikke engang maktet å være fortvilet, det var for energikrevende, forteller Marte, og sier at det gav en helt ny innsikt i hvordan folk har det når de er syke over lang tid.

- Det var så skamfullt å fortelle om diagnosen. ME er stigmatisert blant folk flest, men kanskje aller mest blant kolleger. Jeg meldte blant annet avbud på et kulljubileum for å slippe å fortelle om sykdommen.

Etter nesten et år ble Marte inkludert i rituksimab-studien, en dobbeltblindet placebokontrollert studie, for å undersøke om rituksimab kunne ha effekt mot ME.

- Fordi alle mine plager opplevdes som så fysiske, gav det mening at det måtte en medisin til for å bli frisk. Litt etter foreslo min kloke fastlege henvisning til psykiater Bjarte Stubhaug i Skånevik, innerst i en fjord i Sunnhordland. Jeg ble da tatt ut av rituksimab-studien, men jeg var kommet til et punkt der jeg følte jeg måtte prøve alt.

\section{Snuoperasjonen}

- Så satt jeg da en dag på ferja innover fjorden og heklet - noen goder kom det jo ut av å være syk.

Hun humrer ved tanken på at hun hadde begynt å hekle.

- Jeg hadde ingen forventning om å bli frisk, men trodde jeg skulle lære å mestre sykdommen min bedre. Jeg bestemte meg for å legge bort all legeskepsis og ikke stille kritiske spørsmål i de fire dagene behandlingen skulle vare. Å rygge inn i behandlingen ville være å spenne bein for meg selv. Jeg måtte rett og slett gi det en sjanse og ta spranget fullt og helt.

Hånd i hånd med lett fysisk aktivitet, som likevel var langt ut over det hun hadde turt prøve de to årene hun var syk, var behandlingen konsentrert rundt mindfulness, en moderne versjon av en eldgammel buddhistisk meditasjonstradisjon. 


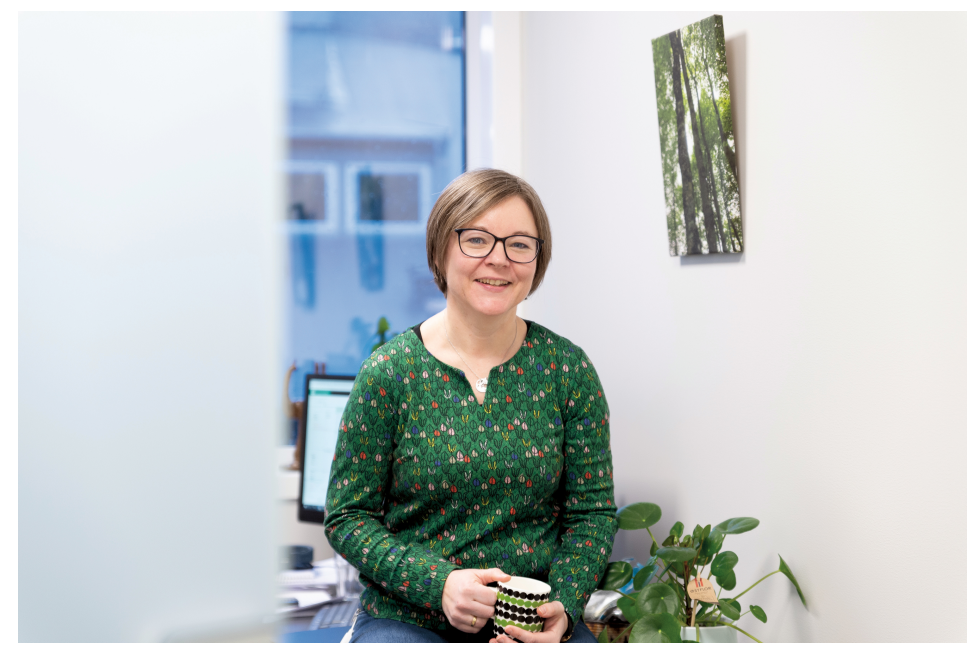

- Mindfulness innebærer også å akseptere livet som det er, fremfor å kjempe mot, samtidig som det også har innslag av metakognitiv terapi - det å kunne forholde seg til tanker og symptomer på en annen måte. Rent fysiologisk tror jeg en av funksjonene til mindfulness er å dempe sympatisk aktivering og dermed dempe stressreaksjoner og aktivering av immunsystemet. Vi lærte blant annet å skifte fokus fra hvordan man har det i kroppen til sansing av ytre ting og å være til stede her og nå.

Å rygge inn i behandlingen ville være å spenne bein for meg selv

I de to årene Marte hadde vært syk, hadde hun automatisert det å holde fokus på energiøkonomisering. Hun hadde lært at hun alltid måtte finne ut hvor mye hun tålte, og så gjøre omtrent 70 \% for ikke å bli mer utmattet.

- Denne monitoreringen var nok hensiktsmessig den første perioden da immunsystemet jobbet mot mononukleosen, men gled så over i en fase der troen på at jeg ikke tålte aktivitet, holdt meg nede.

På fire dager ble Marte Jørgensen frisk. Etter to år. Vi må stoppe opp begge to og dvele litt ved tanken. Marte bryter stillheten:

- Dette var den største snuoperasjonen jeg har hatt i mitt liv, utbryter hun med glød i øynene.

- Det var på grensen til å være magisk!

Samtalen vår glir inn mot Søren Kierkegaards filosofi om at et menneske i eksistensiell krise må kaste seg ut på de 70 ooo favners dyp uten sikkerhetsnett. Hans tanker fra midten av 180o-tallet går rett inn i Martes erfaringer 150 år seinere.

- Det var en lang prosess å komme dit jeg var da jeg tok imot Stubhaugs behandlingstilbud. De to årene jeg var syk, hadde jeg nær sagt tapt alt - jobb, sosialt liv og troen på at jeg kunne utrette noe. Jeg valgte selv å ta imot behandlingstilbudet betingelsesløst. Ingen presset meg, verken NAV eller andre. Det tror jeg er veldig viktig for å få effekt. Valget må komme innenfra. Jeg hadde mye å vinne og lite å tape, og skjønte at hvis jeg gikk halvveis inn, ville jeg sabotere mine egne muligheter til å få utbytte av behandlingen. Å møte noen som sa at jeg ville bli bedre, var også helt nytt for meg og veldig viktig for at jeg skulle våge å ta dette valget.

\section{Frisk}

Oppoverbakker var noe av det Marte unngikk i sykdomsperioden. Vel hjemme ville hun prøve om hun var helt frisk.

- Da var det bare å velge mellom Bergens sju fjell, sier hun med et smil.

Valget falt på Løvstakken. På vei oppover brukte hun teknikkene hun hadde lært. Fokuset var på vinden mot huden, fargene på blomstene og lyden av insekter og fugler, og ikke på kroppen og symptomer. Uten å legge merke til det kom hun lenger enn hun hadde tenkt - 


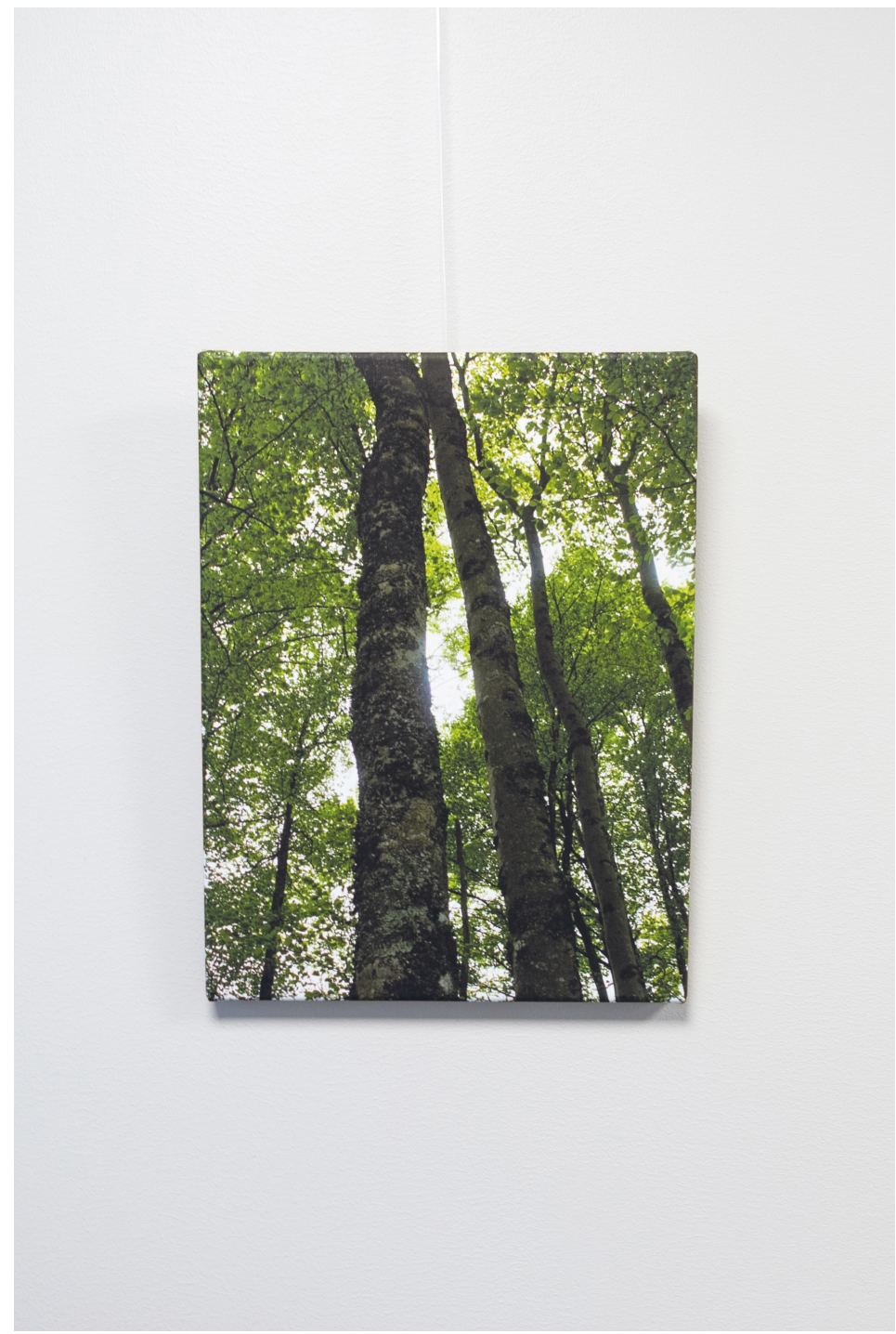

- Tro kan flytte fjell, sier hun, og forteller at det var en enorm mestringsfølelse da hun etter hvert kom så nær toppen at det var for dumt å snu.

- Utsikten jeg fikk, var enorm, og jubelen over å klare det var enda større! Det føltes som om verden lå foran mine føtter - på en helt annen måte denne gangen.

Marte åpner for at selv om hun ble frisk med dette opplegget, behøver ikke det bety at alle med utmattelse vil ha samme utbytte av behandlingen.

- Tilbudet er kontroversielt i deler av ME-miljøet, men at psykologiske metoder virker på ME, beviser ikke at ME er en psykisk tilstand. Symptomene er i høyeste grad fysiske og reelle, men det betyr ikke at vi ikke kan påvirke dem. For meg er det viktig at kroppen er en helhet der det ikke er et skille ved halsen mellom psykiske og fysiske sykdommer. Hjernen er et fantastisk organ med mange uutnyttede muligheter. Behandlingen jeg fikk, spiller på nettopp dette.

\section{Nytt veivalg}

Det er snart ti år siden Marte ble frisk. Hun har valgt en ny karrierevei. Nå jobber hun som psykiater i Helse Bergen med et fire dagers konsentrert behandlingstilbud til pasienter med tvangslidelse og andre angstlidelser.

- Den snuoperasjonen jeg selv gjennomgikk, var en øyeåpner for meg om hva som er mulig selv i det som oppleves som en fastlåst situasjon. Også hos våre pasienter i angstbehandling har jeg sett stor endring i løpet av få dager når de velger å gi helt slipp og gå fullt og helt inn for behandlingen. 
Hun stråler av entusiasme over faget sitt:

- Det er fantastisk å jobbe her med et evidensbasert behandlingstilbud som vi vet virker. Fordi effekten er så godt dokumentert, formidler vi en trygghet og tro på bedring som gjør det lettere for pasienten å velge å ta imot behandlingen, selv om den er krevende.

- Fire dagers intensiv behandling - blir ikke pasientene veldig slitne underveis?

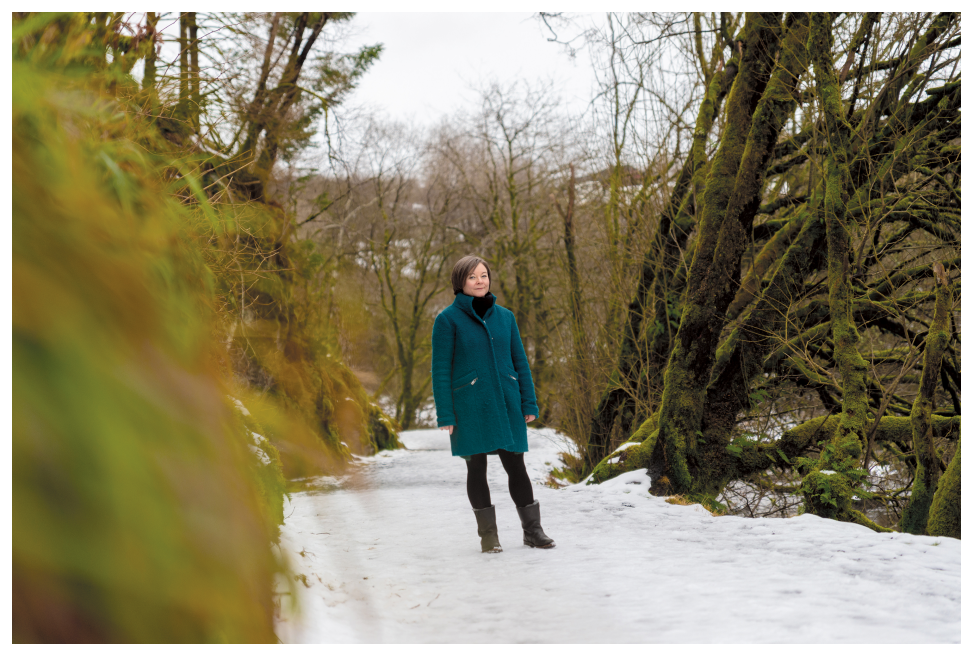

- Jo, men samtidig opplever pasientene en enorm lettelse ved å mestre ting de ikke har trodd de skulle klare. Selv om det er svært krevende, synes de det er verdt innsatsen. Jeg tror at noe av årsaken til at pasientene velger et så krevende behandlingstilbud som de får hos oss, er at det er så mye lidelse i deres liv at de er villige til å kaste seg ut på dypt vann, akkurat slik jeg valgte da jeg dro til Skånevik.

\section{Hvordan virker behandlingen?}

Marte har reflektert mye over hva som egentlig skjedde i Skånevik.

- Nå som jeg har et faglig grunnlag og en viss distanse til det som skjedde, synes jeg det er logisk at behandlingen virket. Stubhaug gav meg tro og håp på å kunne bli bedre. Dette satte meg i stand til å ta en avgjørelse om å gå fullt og helt inn for opplegget og endret hele innstillingen til at jeg var uhelbredelig syk. Han gav meg så noen helt konkrete teknikker for å slutte å fokusere på symptomer og ikke minst slutte å monitorere dem.

Hjernen er et fantastisk organ med mange uutnyttede muligheter

- Det er trist å tenke på at blant annet bostedsadresse bestemmer hvilken behandling man får. Generelt faller ME-pasientene mellom flere stoler. Psykiatrien ser på dem som somatisk syke, mens somatikken ofte ikke har behandling å tilby, sier hun og fortsetter:

- Når det gjelder min historie, tror jeg vi kan dele sykdomsforløpet i to. I begynnelsen var det en immunologisk prosess som skapte symptomene, og for å klare meg i den fasen var det viktig å unngå aktivitet. Men så gled jeg inn i neste fase der immunologien var mindre fremtredende, og da var det redselen for mer utmattelse som opprettholdt symptomene. Det var ikke mulig for meg å merke denne endringen, det føltes helt likt, og jeg fortsatte derfor å håndtere meg selv som jeg hadde gjort i tilstandens tidlige fase.

\section{Recovery Norge}

Først nå velger hun å gå ut med sin historie. I 2019 holdt hun et foredrag for leger i København med tittelen «Mitt livs snuoperasjon». Hun er også aktiv i et nettverk som heter Recovery Norge, der man ønsker å formidle at det er mulig å bli frisk av ME.

- De som blir friske, blir fort usynlige. Det å stikke seg frem som helbredet for ME gir ofte negativ oppmerksomhet, ikke minst i ME-miljøet, og er man blitt frisk, vil man jo helst legge det hele bak seg. Etter at vi har fortalt våre historier, vet vi at flere ME-pasienter har valgt å ta imot behandling og blitt friske. Det er så sterkt at det er verdt ubehaget med å gå 
ut med min historie.

Vi sitter på kontoret til Marte. Det er lite, spartansk innredet, men ryddig. På veggen har Marte hengt opp et vakkert, men litt unnselig bilde hun tok da hun var i behandling i Skånevik. Vi ser vakre bøketrestammer som bader i lysegrønt bladverk.

- Det vekker gode assosiasjoner og fungerer som en huskelapp for hvordan mindfulness hjalp meg i min store snuoperasjon. Jeg ser på bildet hver dag og kjenner på hvor takknemlig jeg er for at jeg fikk rett behandling på rett tid, avslutter hun.

Publisert: 30. mars 2020. Tidsskr Nor Legeforen. DOI: 10.4045/tidsskr.20.0172

(C) Tidsskrift for Den norske legeforening 2020. Lastet ned fra tidsskriftet.no 